\title{
Effect of Energy Consumption on Human Development in the Countries of the Economic and Monetary Community of Central Africa (EMCCA)
}

\author{
Hermann Clachel Lekana, Constant Bruno Serges Ikiemi \\ Faculty of Economic Sciences, Laboratory of Economic and Social Research and Studies, Brazzaville, Congo \\ Email: hermann.lekana@umng.cg, sergesikiemi@yahoo.fr
}

How to cite this paper: Lekana, H. C., \& Ikiemi, C. B. S. (2021). Effect of Energy Consumption on Human Development in the Countries of the Economic and Monetary Community of Central Africa (EMCCA). Theoretical Economics Letters, 11, 404-421. https://doi.org/10.4236/tel.2021.113027

Received: March 13, 2021

Accepted: May 7, 2021

Published: May 10, 2021

Copyright () 2021 by author(s) and Scientific Research Publishing Inc. This work is licensed under the Creative Commons Attribution International License (CC BY 4.0).

http://creativecommons.org/licenses/by/4.0/

\begin{abstract}
The purpose of this article is to analyze the effects of energy consumption on human development in the EMCCA over the period from 1990 to 2019. An econometric analysis using panel data and particularly the Driscoll-Kraay technique has shown that in EMCCA countries, energy consumption is a factor that improves human development, while renewable energy consumption has a marginal effect on human development. These results imply, on the one hand, the improvement of energy levels in key development sectors and rural areas and, on the other hand, the development of the clean energy sector.
\end{abstract}

\section{Keywords}

Energy Consumption, Renewable Energy, Human Development, CEMAC

\section{Introduction}

Human development inequalities remain a major concern for the world, and the United Nations Development Programme (UNDP) dedicates a global, regional or even national report to it each year. For the UNDP (2019), inequalities in human development are influenced by basic capabilities (deprivation of essential needs) and advanced capabilities (the actions of humans in society). Indeed, regarding the deprivation of needs, the UNDP (2015) acknowledged that energy deprivation is one of the obstacles to achieving the SDGs by 2030. With regard to human action in society, the COPs $(15,19$ and 21) highlighted the link between energy and the environment. We notice that regardless of the type of capability, 
energy plays a crucial role in its reduction.

For Karekezi et al. (2012), inaccessibility to basic energy services contributes to keeping poor people in a vicious cycle of poverty and thus hinders human development. This view is also supported by the United Nations Conference on Trade and Development (UNCTAD, 2017). For this institution, access to energy services in general and modern energy services, in particular, is essential for poverty eradication, economic growth, job creation, social services and, in general, the promotion of human development. Concerns about the link between energy use and human development are apparent in both the evidence and the literature.

On a factual level, it is worth mentioning that human development, as measured by the Human Development Index (HDI), stood at 0.707 in the world and 0.507 in Sub-Saharan Africa in 2018, with this subregion, ranked last in the world. With regard to the EMCCA, the UNDP report (2019) shows that the HDI level slightly increased in EMCCA countries from 1990 to 2000 and 2018, with averages of 0.520, 0.503, and 0.591, respectively. Indeed, in 2019, Gabon was the highest-ranked country, followed by Congo and Cameroon, with respective ranks of 119,149 , and 153 out of 189 countries. During the same period, energy consumption in CEMAC countries, which is captured by final consumption and the consumption of renewable energy, was at levels of approximately 125,591 koe for total energy consumption and 73,728 koe for renewable energy. This makes the EMCCA the subregion with the lowest level of energy consumption, despite the high potential it holds. These facts show that the EMCCA has both a low level of energy consumption and a low level of human development, which makes it a particularly interesting area for research to analyze the effects of energy consumption on human development.

In terms of the economic literature, the work on the relationship between energy consumption and human development is moving in two directions. In the first direction, there is a controversy between, on the one hand, the orthodox view (Solow, 1956; Becker et al., 1990; Sen, 1999; Sinha \& Sen, 2016; Menegaki, 2011), which does not acknowledge the contribution of energy to development and thus to human development and, on the other hand, the heterodox review (Hansen \& Percebois, 2010; Kané, 2009; Jumbe, 2004), according to which energy influences human development. In the second direction, we find the proponents of energy transition theory (Hosier \& Dowd, 1987; Wang et al., 2020; Wang et al., 2018; Pirlogea, 2012). For the latter, the relationship between energy consumption and human development depends on the quantity and quality of energy. Therefore, the more developed a country is (high human development), the less it consumes fossil or unsuitable energy.

These controversies in the literature show that the relationship between energy consumption and human development is still relevant, thus justifying this research. Thus, the central question that structures the problem of this research is as follows: what are the effects of energy consumption on human development? 
The objective of this paper is to analyze the effects of energy consumption on human development. Considering that energy consumption contributes to the improvement of income, which favors access to health and education, it is argued in this paper that energy consumption is beneficial for human development. The rest of this work is presented as follows. The second section is devoted to a literature review on the relationship between energy consumption and human development. The third section is devoted to the methodology. The fourth section is devoted to the presentation and interpretation of the results, and finally, the fifth section addresses the conclusion and the economic policy implications.

\section{Review of the Literature on the Relationship between Energy Consumption and Human Development}

Since the work of Kraft and Kraft (1978), the contribution of energy consumption in the economic sphere has been of constant concern to economists, and there is an abundant body of literature on the effects of energy consumption on human development. The latter is the subject of this section, in which we first address the theoretical review and then the empirical review.

\subsection{Effects of Energy Consumption on Human Development in the Theoretical Literature}

The literature on the relationship between energy consumption and human development is moving in two directions. First, there are two controversial approaches, namely, the orthodox approach and the heterodox approach. In the orthodox approach, which is based on growth theories (traditional and endogenous) and the theory of human development developed by Sen $(1992,1999)$, energy consumption is not a primary factor for growth and human development. In other words, human development depends not on energy consumption but on other economic and noneconomic factors. Thus, to support their arguments, scholars use two hypotheses: conservation and neutrality.

The first hypothesis suggests that energy consumption is a crucial component of economic growth, whether direct or indirect, and that energy is a complement to capital and labor in the production function (Apergis \& Payne, 2009). The second is that energy consumption has no economic impact on growth. This assumption holds when there is no evidence of causality between energy consumption and economic growth. Thus, energy conservation policy has no effect on real GDP or economic growth (George \& Nickoloas, 2011).

In contrast, the heterodox approach is based on the environmentalist or ecological vision. For the proponents of this approach (Georgescu-Roegen, 1979; Stern, 2012), energy is an indispensable, even primary, factor for economic growth and hence human development. To support this point of view, these authors put forward two hypotheses. The first is the so-called growth hypothesis, which suggests that energy consumption is an important component of economic 
growth and even of human development. At this level, energy consumption is treated directly as a factor of production in addition to capital and labor. The second hypothesis is called the feedback hypothesis. This indicates that energy consumption and economic growth affect each other. Thus, this hypothesis suggests the existence of a bidirectional causal relationship between energy consumption and economic growth (Belke et al., 2010).

Energy transition theory incorporates the second direction of analysis of the relationship between energy consumption and human development. This theory builds on the work of Hosier and Dowd (1987) and Leach (1992), who posited that as income increases, energy consumers tend to transition from traditional or inferior energy to modern energy due to ease of use and comfort. Thus, Chiroleu-Assouline (2001) maintained that the energy transition has a double dividend. First, it reduces the consumption of fossil fuels, which improves the health of populations. Second, it increases the purchasing power of populations due to energy bill decreases. This double dividend is beneficial for human development in terms of improvements in income, health and education.

\subsection{Effects of Energy Consumption on Human Development in the Empirical Literature}

Empirically, the relationship between energy consumption and human development can be divided into two groups. On the one hand, some work emphasizes the existence of a positive link between energy consumption and human development, and on the other hand, some research aims to qualify this positive link.

With regard to the works that put forward the existence of a positive link, it is worth noting that the first studies were limited to establishing the correlations between energy consumption and human development. To this end, Pasternak (2000) studied the relationship between the HDI and energy and electricity consumption using 1997 data. He found that the HDI and energy consumption per capita are strongly positively correlated and identified an electricity threshold for a maximum HDI; in other words, energy consumption and HDI have the same behavior. When energy consumption increases (decreases), the HDI also increases (decreases). Using the same approach, Martınez and Ebenhack (2008) studied the correlation between the HDI and energy consumption per capita for one hundred and twenty (120) nations. They found similar behavior between the index values and energy for the majority of countries in the world. During the same period, Kanagawa and Nakata (2008), using a bottom-up equilibrium model, found that access to electricity improves socioeconomic conditions in rural areas of developing countries. They also showed that electricity consumption has a positive and significant correlation with GDP as well as with the HDI for one hundred and twenty (120) developing countries.

The second wave of work is based on econometric analysis of the relationship between energy consumption and human development. In this regard, Pirlogea 
(2012) analyzed the effect of fossil fuels and renewable energy on human development in six (06) European countries (Bulgaria, Romania, Poland, Portugal, Ireland and Netherlands) over a period from 1997 to 2008. This author estimated a fixed effect model using the generalized least squares technique for time series data. The results obtained reveal that both fossil fuels and renewable energies have a positive effect on human development. For Kazar and Kazar (2014), the link between renewable energy consumption and human development was the focus of their study of one hundred and fifty-four (154) countries during the period 1980-2010. Their results suggested the existence of bidirectional causality between human development and renewable energy consumption. Wang et al. (2020) investigated the role of debt in the relationship between renewable energy consumption and human development in BRICS countries over the 1990-2016 period. Using a set of methods to address the cross-sectional dependence issue (Westerlund panel cointegration test, Driscoll-Kraay robust standard error estimates, and Dumitrescu-Hurlin causality test), the results indicated that human development is driven by renewable energy use. On the other hand, public debt is detrimental to human development, and the interaction term between renewable energy consumption and public debt reduces the level of human development.

Regarding work qualifying the existence of a positive link, Ouedraogo (2013) focused on the analysis of the relationship between energy consumption and electricity consumption and the HDI in fifteen developing countries over the period from 1988 to 2008. The short-term results showed that energy and electricity consumption have a neutral effect on the HDI, while in the long run, the results clearly confirm the existence of a negative cointegration relationship between energy consumption and the HDI. Similarly, Niu et al. (2013) examined the causality between electricity consumption and the level of human development, in which life expectancy at birth, the urbanization rate, the adult literacy rate, consumption and GDP per capita were used as development indicators. The authors used several techniques (cointegration, panel causality and panel fixed effects models) and analyzed fifty (50) developed and developing countries. Their results did not confirm the existence of a short-term causal relationship between the five indicators and electricity consumption. Considering the long term, the bidirectional relationship was verified for some countries.

Furthermore, Wang et al. (2018) explored the relationship between renewable energy consumption, economic growth and the human development index for 1990-2014 in Pakistan using the double least squares method. The results revealed that renewable energy consumption does not improve human development in Pakistan. A similar result was obtained by Tran et al. (2019) in studying ninety (90) countries over the period 1990 to 2014. They found, in fact, that there is no significant causal relationship between energy consumption and human development, either for the whole sample or for the subpanels.

The theoretical and empirical literature on the relationship between energy 
consumption and human development shows that these two phenomena are not always interdependent. The work available in the literature does not indicate a consensus on the meaning of the relationship and its importance, which means that this issue remains relevant. The literature also suggests that energy consumption is approximated by the total or renewable form. Regarding human development, the development index seems to take precedence over the other variables. As a result of the above, the present study will use the same variables mentioned above to conduct an experiment in the EMCCA countries in order to contribute to the literature on this issue.

\section{Methodology}

The objective of this paper is to analyze the effects of energy consumption on human development. To achieve this, we have drawn on the work of Pirlogea (2012), Ouedraogo (2013) and Wang et al. (2020). According to these authors, human development depends on several factors, among which we can integrate energy. Thus, the formalization is as follows:

$$
H_{i t}=f\left(E_{i t}, X_{i t}\right)
$$

where $H$ is human development, $E$ is energy consumption and $X$ refers to the other variables that can explain human development. $i$ and $t$ correspond respectively to the number of countries and the period.

For Wang et al. (2018) and Nguyen et al. (2019), several factors (investment, environment, debt, price, and human capital), but not energy, can explain human development. Therefore, the variable $X$ becomes:

$$
X_{i t}=Q\left(\text { Invpub }_{i t}, \text { Invpri }_{i t}, E n v_{i t}, \text { Debt }_{i t}, P_{i t}, K h_{i t}\right)
$$

Incorporating (2) into (1), we obtain:

$$
H_{i t}=f\left(E_{i t}, \text { Invpub }_{i t}, \text { Invpri }_{i t}, E n v_{i t}, \text { Debt }_{i t}, P_{i t}, K h_{i t}\right)
$$

Assuming that function (3) is a semilogarithmic function and inserting the Neperian logarithm operator to linearize, Equation (3) is as follows:

$$
\begin{aligned}
& H_{i t}=\alpha_{0}+\alpha_{1} \ln E_{i t}+\alpha_{2} \ln \text { Invpub }_{i t}+\alpha_{3} \ln \text { Invpri }_{i t}+\alpha_{4} \ln E n v_{i t} \\
& +\alpha_{5} \ln D e b t_{i t}+\alpha_{6} P_{i t}+\alpha_{7} \ln K h_{i t}+\varepsilon_{i t}
\end{aligned}
$$

Considering that Equation (4) can be estimated with total energy consumption and renewable energy consumption, we obtain Equations (5) and (6):

$$
\begin{aligned}
H_{i t}= & \alpha_{0}+\alpha_{1} \ln E_{i t}+\alpha_{2} \ln \text { Invpub }_{i t}+\alpha_{3} \ln \text { Invpri }_{i t}+\alpha_{4} \ln E n v_{i t} \\
& +\alpha_{5} \ln D_{e b t_{i t}}+\alpha_{6} P_{i t}+\alpha_{7} \ln K h_{i t}+\varepsilon_{i t}
\end{aligned}
$$

and

$$
\begin{aligned}
H_{i t}= & \alpha_{0}+\alpha_{1} \ln E R_{i t}+\alpha_{2} \ln \text { Invpub }_{i t}+\alpha_{3} \ln \text { Invpri }_{i t}+\alpha_{4} \ln E n v_{i t} \\
& +\alpha_{5} \ln \operatorname{Debt}_{i t}+\alpha_{6} P_{i t}+\alpha_{7} \ln K h_{i t}+\varepsilon_{i t}
\end{aligned}
$$

where $H_{i t}$ is human development, which is captured by the human development index; $E_{i t}$ is total energy consumption, a variable that impacts the human development index negatively in developed countries and positively in de- 
veloping countries; $E R_{i t}$ is renewable energy consumption, which has a positive impact on the human development of the states; Invpub $b_{i t}$ is public investment, approximated by gross fixed capital formation; Invpri $_{i t}$ is private investment, captured by foreign direct investment, which should have a positive effect on the level of human development because of the contribution of new knowledge; $E n v_{i t}$ is the environment proxied by carbon dioxide emissions, and this variable, according to the literature, has a negative influence on human development; $D e b t_{i t}$ is debt, approximated by external debt, with the expectation that this variable negatively affects human development; and $P_{i t}$ is the price is captured by inflation, and knowing the role it plays in household consumption, it has a negative impact on the dependent variable. For $K h_{i t}$, as shown in the literature, educated capital improves the level of human development. Approximated by the gross primary school enrollment rate, it should have a positive influence on human development. $\alpha_{0}, \cdots, \alpha_{8}$ are the parameters of the model.

\section{Data Source}

The data used in this paper are taken from the World Bank's World Development Indicators (WDI, 2021) and the Bank of Central African States (BEAC, 2021) databases. The study focuses on three EMCCA countries that have been producing oil since 1990 (Cameroon, Congo, Gabon) and covers the period from 1990 to 2019. It should be noted, however, that this range was dictated by data availability.

\section{Presentation and Discussion of Results}

The macro nature of this panel leads us to use the same approach as for studies using time series. Consequently, this approach begins with a study of the dynamic properties of the series before checking whether they are cointegrated. As a result, this analysis begins with stationarity tests and continues with a study of the integration relationship between the different series in order to avoid spurious regressions (Lékana \& Ndinga, 2020). Thus, we first describe the execution of the model and present the results, and then we interpret these results. Before discussing these tests, we first present the descriptive statistics and finally a correlation analysis of the EMCCA zone. Table 1 below presents the descriptive statistics for the three EMCCA countries.

Table 1 shows that the average HDI level is 0.544 among the three countries, with the highest level recorded in Gabon in 2019 and the lowest level in Cameroon in 1996. However, there is little dispersion in these countries since the standard deviation is low compared to the mean. In terms of final energy consumption, the average levels are approximately 109.247 toe and 75.553 toe for renewable energy. The maximum is recorded in Gabon during 2009 and 2010 for respective levels of 88.096 koe for renewable energy and 217.064 koe for final energy. The minimum values of energy consumption are recorded in Congo during the years 2010 and 2000 for renewable energy, and they were 55.150 koe 
Table 1. Descriptive statistics.

\begin{tabular}{|c|c|c|c|c|c|c|}
\hline Variables & & Mean & Standard deviation & Minimum & Maximum & Observations \\
\hline & Overall & 0.544 & 0.082 & 0.431 & 0.703 & $\mathrm{~N}=90$ \\
\hline \multirow[t]{3}{*}{ HDI } & Between & & 0.088 & 0.482 & 0.644 & $\mathrm{n}=3$ \\
\hline & Within & & 0.038 & 0.493 & 0.625 & $\mathrm{~T}=30$ \\
\hline & Overall & 75.553 & 8.833 & 55.150 & 88.096 & $\mathrm{~N}=90$ \\
\hline \multirow[t]{3}{*}{ CER } & Between & & 8.524 & 65.834 & 81.760 & $\mathrm{n}=3$ \\
\hline & Within & & 5.389 & 64.869 & 89.873 & $\mathrm{~T}=30$ \\
\hline & Overall & 109.247 & 42.308 & 51.116 & 217.064 & $\mathrm{~N}=90$ \\
\hline \multirow[t]{3}{*}{ CET } & Between & & 29.554 & 75.146 & 127.439 & $\mathrm{n}=3$ \\
\hline & Within & & 34.657 & 48.006 & 201.155 & $\mathrm{~T}=30$ \\
\hline & Overall & 4.274 & 8.107 & -8.703 & 39.442 & $\mathrm{~N}=90$ \\
\hline \multirow[t]{3}{*}{ FDI } & Between & & 4.109 & 1.233 & 8.948 & $\mathrm{n}=3$ \\
\hline & Within & & 7.371 & -13.378 & 34.767 & $\mathrm{~T}=30$ \\
\hline & Overall & 27.339 & 11.484 & 14.305 & 79.462 & $\mathrm{~N}=90$ \\
\hline \multirow[t]{3}{*}{ GFCF } & Between & & 7.080 & 21.345 & 35.151 & $\mathrm{n}=3$ \\
\hline & Within & & 9.904 & 9.420 & 71.651 & $\mathrm{~T}=30$ \\
\hline & Overall & 5.358 & 5.562 & 0.784 & 36.738 & $\mathrm{~N}=90$ \\
\hline \multirow[t]{3}{*}{ DEBT } & Between & & 1.890 & 3.177 & 6.532 & $\mathrm{n}=3$ \\
\hline & Within & & 5.341 & -0.203 & 35.565 & $\mathrm{~T}=30$ \\
\hline & Overall & 0.132 & 0.065 & 0.003 & 0.278 & $\mathrm{~N}=90$ \\
\hline \multirow[t]{3}{*}{$\mathrm{CO}_{2}$} & Between & & 0.070 & 0.083 & 0.212 & $\mathrm{n}=3$ \\
\hline & Within & & 0.030 & 0.052 & 0.214 & $\mathrm{~T}=30$ \\
\hline & Overall & 115.484 & 20.393 & 58.351 & 146.582 & $\mathrm{~N}=90$ \\
\hline \multirow[t]{3}{*}{ TBSP } & Between & & 21.721 & 99.215 & 140.1507 & $\mathrm{n}=3$ \\
\hline & Within & & 9.890 & 66.749 & 132.479 & $\mathrm{~T}=30$ \\
\hline & Overall & 3.681 & 7.517 & -11.686 & 42.440 & $\mathrm{~N}=90$ \\
\hline \multirow[t]{2}{*}{ INFLATION } & Between & & 1.254 & 2.633 & 5.070 & $\mathrm{n}=3$ \\
\hline & Within & & 7.446 & -10.638 & 41.050 & $\mathrm{~T}=30$ \\
\hline
\end{tabular}

Source: Author, based on data from WB (2021) and BEAC (2021).

and 51.116 koe for overall energy consumption. It should be noted that regardless of the type of energy, CEMAC countries are faced with a strong disparity.

Table 2 shows that the HDI is strongly correlated with the gross primary school enrollment rate and $\mathrm{CO}_{2}$ emissions and that both move in the same direction. With the exception of inflation, which is weakly and negatively correlated with the HDI, the other variables are weakly and positively correlated with the HDI. With respect to the energy consumption variable, we note that there is an average and positive correlation between final energy consumption and renewable energy consumption. There is also a medium and negative correlation with inward foreign direct investment and gross fixed capital formation. 
Table 2. Correlation matrix.

\begin{tabular}{|c|c|c|c|c|c|c|c|c|c|}
\hline & HDI & CER & CET & FDI & GFCF & DEBT & $\mathrm{CO}_{2}$ & TBSP & INFLATION \\
\hline HDI & 1.00 & & & & & & & & \\
\hline CER & 0.07 & 1.00 & & & & & & & \\
\hline CET & 0.25 & 0.69 & 1.00 & & & & & & \\
\hline FDI & 0.13 & -0.44 & 0.03 & 1.00 & & & & & \\
\hline GFCF & 0.13 & -0.52 & -0.15 & 0.44 & 1.00 & & & & \\
\hline DEBT & 0.02 & 0.00 & -0.21 & -0.15 & 0.05 & 1.00 & & & \\
\hline $\mathrm{CO}_{2}$ & 0.81 & 0.12 & 0.04 & -0.07 & 0.05 & 0.29 & 1.00 & & \\
\hline TBSP & 0.87 & 0.03 & 0.05 & -0.01 & 0.02 & 0.25 & 0.84 & 1.00 & \\
\hline INFLATION & -0.15 & 0.07 & -0.10 & -0.11 & 0.11 & 0.39 & 0.02 & -0.10 & 1.00 \\
\hline
\end{tabular}

Source: Author, based on data from WB (2021) and BEAC (2021).

\subsection{Stationarity Tests}

The quest for unit roots in panel data has evolved dramatically in a short time. Currently, there are two ways to approach unit root tests. The first approach includes tests that admit the existence of an independent cross-sectional unit (Maddala \& Wu, 1999; Choi, 2001; Levin et al., 2002; Breitung, 2003; Hadri, 2000), while the second involves the existence of a dependent cross-sectional unit (Pesaran, 2004; Moon \& Perron, 2004; Bai \& Ng, 2004).

In this study, we perform two unit root tests. The first-generation tests are the test of Levin, Lin and Chu (2002), in which the autoregressive root is assumed to be homogeneous under the alternative hypothesis, and the test of Im, Pesaran and Shin (2003), in which the autoregressive root is assumed to be heterogeneous under the alternative hypothesis. The results of the stationarity tests are presented in Table 3 below.

The table above shows that the variables are stationary in levels and in first differences. Indeed, the first-generation stationarity tests show that the inflation variable is the only one that is stationary in levels in both cases. For the rest, we notice that with the LLC test, all the variables are stationary at the $1 \%$ threshold and $5 \%$ in the first difference. Unlike this test, the IPS test shows that except for the $\mathrm{HDI}, \mathrm{TBSP}, \mathrm{CET}, \mathrm{CER}$ and $\mathrm{CO}_{2}$ variables, the others are stationary.

\subsection{Panel Cointegration Test}

The regression of one of these variables on the others could lead to spurious results if the variables are not cointegrated. To avoid this drawback, it is necessary to perform a cointegration test to check whether the variables are cointegrated. The Westerlund test developed by Westerlund (2007) and Persyn and Westerlund (2008) is a cointegration test based on the error correction model. The data generating process is considered a priori to be an error correction model. The test is performed on the parameter that represents the speed of adjustment, i.e., 
Table 3. Stationarity tests.

\begin{tabular}{ccccc}
\hline & \multicolumn{2}{c}{ IPS } & \multicolumn{2}{c}{ LLC } \\
\cline { 2 - 5 } & Level & First difference & Level & First difference \\
\hline HDI & $0.8515(0.8028)$ & $-3.4792(0.0003)$ & $3.1986(0.9993)$ & $-2.5414(0.0055)$ \\
GFCF & $-2.2990(0.0108)$ & & $0.2044(0.5810)$ & $-8.1382(0.0000)$ \\
DEBT & $-3.6185(0.0001)$ & & $-1.5940(0.0555)$ & $-7.6445(0.0000)$ \\
CET & $0.9816(0.8368)$ & $-4.4187(0.0000)$ & $-0.2799(0.3898)$ & $-5.7437(0.0000)$ \\
CER & $-0.0196(0.4922)$ & $-5.0610(0.0000)$ & $-0.8304(0.2032)$ & $-6.2658(0.0000)$ \\
FDI & $-3.1970(0.0007)$ & & $-0.9740(0.1650)$ & $-9.0613(0.0000)$ \\
CO 2 & $-1.5644(0.0589)$ & $-5.9920(0.0000)$ & $-1.2159(0.1120)$ & $-9.2808(0.0000)$ \\
INFLATION & $-4.2235(0.0000)$ & & $-5.2210(0.0000)$ & \\
TBSP & $-0.6457(0.2592)$ & $-4.9371(0.0000)$ & $-0.8559(0.1960)$ & $-8.4902(0.0000)$ \\
\hline
\end{tabular}

Source: Author, using results from Stata.

the speed at which the system returns to equilibrium after a shock. If the parameter is less than zero, then there is an error correction, so the variables are cointegrated.

The objective of this test is to verify the null hypothesis of the absence of cointegration by questioning the existence of an error correction model for each or for all of the individuals in the panel. These four tests are divided into two groups: "P" and "G". The "P" tests, of which there are two in total (Pt and $\mathrm{Pa}$ ), test the null hypothesis of the absence of a cointegrating relationship in the panel as a whole against the alternative hypothesis of the existence of a cointegrating relationship. The "G" tests, which are also two in number (Gt and $\mathrm{Ga}$ ), test the hypothesis of the absence of a cointegrating relationship for all individuals in the panel against the alternative hypothesis of the existence of at least one relationship at the individual level, for which the variables are cointegrated (Ndinga et al., 2017). The results of the cointegration tests are presented in Tables 4-6 below.

The reading of the Kao test table shows that out of the five statistics that it contains, only two (Modified Dickey-Fuller $t$ and Unadjusted modified Dickey-Fuller $\mathrm{t}$ ) present significant probabilities at the 5\% threshold in both models. Faced with these results, we can conclude that the variables are cointegrated.

In Table 5, we also find two significant statistics (Modified variance ratio and Modified Phillips-Perron t) out of the seven in the Pedroni test for the renewable energy consumption model. For the total energy consumption model, we notice that all the statistics are significant at the $1 \%$ threshold. Similar to the results for the previous test, we conclude that there is a cointegration relationship.

The results of the Westerlund test presented in the table above show that in both conditions, "P and G" are significant at the $1 \%$ and $5 \%$ levels, thus confirming the results of the Kao and Pedroni tests. 
Table 4. KAO test.

\begin{tabular}{ccccc}
\hline & \multicolumn{2}{c}{ MODEL CET } & \multicolumn{2}{c}{ MODEL CER } \\
\cline { 2 - 5 } & Statistic & $p$-value & Statistic & $p$-value \\
\hline Modified Dickey-Fuller t & -2.7551 & 0.0029 & -2.0937 & 0.0181 \\
Dickey-Fuller t & -1.0941 & 0.1369 & -0.9421 & 0.1731 \\
Augmented Dickey-Fuller t & 0.6889 & 0.2454 & 1.1273 & 0.1298 \\
Unadjusted modified Dickey-Fuller t & -1.9759 & 0.0241 & -1.9969 & 0.0229 \\
Unadjusted Dickey-Fuller t & -0.8644 & 0.1937 & -0.9087 & 0.1817 \\
\hline
\end{tabular}

Source: Author based on results from Stata.

Table 5. Pedroni test.

\begin{tabular}{ccccc}
\hline & \multicolumn{2}{c}{ MODEL CET } & \multicolumn{2}{c}{ MODEL CER } \\
\cline { 2 - 5 } & Statistic & $p$-value & Statistic & $p$-value \\
\hline Modified variance ratio & -2.8489 & 0.0022 & -2.7203 & 0.0033 \\
Modified Phillips-Perron t & 2.5853 & 0.0049 & 0.9493 & 0.1712 \\
Phillips-Perron t & 2.7982 & 0.0026 & -0.9735 & 0.1652 \\
Augmented Dickey-Fuller t & 2.5594 & 0.0052 & -0.0888 & 0.4646 \\
Modified Phillips-Perron t & 2.9852 & 0.0014 & 1.5704 & 0.0582 \\
Phillips-Perron t & 2.5701 & 0.0051 & -0.6691 & 0.2517 \\
Augmented Dickey-Fuller t & 2.3413 & 0.0096 & 0.2049 & 0.4188 \\
\hline
\end{tabular}

Source: Author based on results from Stata.

Table 6. Westerlund test.

\begin{tabular}{|c|c|c|c|c|c|}
\hline & & \multicolumn{2}{|c|}{ MODEL CET } & \multicolumn{2}{|c|}{ MODEL CER } \\
\hline & & Statistic & $p$-value & Statistic & $p$-value \\
\hline & & & & & \\
\hline \multirow[t]{2}{*}{ Variance } & ratio & 5.1462 & 0.0000 & 4.8973 & 0.0000 \\
\hline & & \multicolumn{4}{|c|}{ Gt et $\mathrm{Ga}$} \\
\hline Variance & Ratio & 1.7370 & 0.0412 & 1.6528 & 0.0492 \\
\hline
\end{tabular}

Source: Author based on results from Stata.

\subsection{Estimation Method}

The three EMCCA countries are all oil producers and have the same financial regulations. Thus, they may experience common shocks, such as the oil crises of the 1970s or the global financial crisis starting in 2007. This type of correlation may result from common global shocks with heterogeneous impacts. It can also be the result of local spillovers between countries or regions. In these situations, the appropriate method is Driscoll-Kraay (Driscoll \& Kraay, 1998). Developed by Driscoll-Kraay under the inspiration of the work of Newey \& West (1987), in time series, the DK method provides a nonparametric covariance matrix esti- 
mator that is robust to very general forms of spatial error and temporal dependence. Thus, unlike standard estimators (DOLS and the FMLOS), this DK technique accounts for all forms of cross-sectional, temporal, and spatial dependence (Ozokcu \& Özdemi, 2017; Sarkodie \& Strezov, 2019). According to Hoechle (2007), erroneously ignoring spatial correlation in panel regressions typically leads to overly optimistic estimates. Table 7 below presents the results from the DK method and the fixed effect model:

The reading of Table 7 shows that the models present coefficients of determination higher than $50 \%$. We note that the Pearsan tests are also significant, which validates the use of the Driscoll \& Kraay (1998) technique. In view of this information, we can conclude that the estimates are convincing. It is also important to note the absence of carry-over effects on the coefficients.

The analysis of the results shows that total external debt and inflation have a negative effect on the HDI and that only total external debt is significant at the

Table 7. Results of the estimations.

\begin{tabular}{|c|c|c|c|c|}
\hline \multicolumn{5}{|c|}{ Endogenous variable: HDI } \\
\hline & \multicolumn{2}{|c|}{ MODEL CET } & \multicolumn{2}{|c|}{ MODEL CER } \\
\hline & $\begin{array}{c}\text { Fixed } \\
\text { Effect Model }\end{array}$ & $\begin{array}{c}\text { Modèle } \\
\text { Driscoll-Kraay }\end{array}$ & $\begin{array}{c}\text { Fixed } \\
\text { Effect Model }\end{array}$ & $\begin{array}{c}\text { Modèle } \\
\text { Driscoll-Kraay }\end{array}$ \\
\hline $\begin{array}{l}\text { Total energy } \\
\text { consumption }\end{array}$ & $\begin{array}{l}0.0002 \\
(1.05)\end{array}$ & $\begin{array}{c}0.0002^{* *} \\
(2.37)\end{array}$ & & \\
\hline $\begin{array}{c}\text { Renewable } \\
\text { energy consumption }\end{array}$ & & & $\begin{array}{l}0.0002 \\
(0.17)\end{array}$ & $\begin{array}{c}0.0002 \\
(0.3)\end{array}$ \\
\hline $\begin{array}{l}\text { Gross capital } \\
\text { formation fixed }\end{array}$ & $\begin{array}{c}0.0008^{\star * *} \\
(4.52)\end{array}$ & $\begin{array}{c}0.0008^{* *} \\
(2.44)\end{array}$ & $\begin{array}{c}0.0010^{\star * *} \\
(5.08)\end{array}$ & $\begin{array}{c}0.0010^{\star * *} \\
(2.75)\end{array}$ \\
\hline Total external debt & $\begin{array}{l}-0.0021^{* *} \\
(-2.38)\end{array}$ & $\begin{array}{c}-0.0021^{* * *} \\
(-3.29)\end{array}$ & $\begin{array}{c}-0.0020^{* * *} \\
(-2.75)\end{array}$ & $\begin{array}{l}-0.0020^{* *} \\
(-2.41)\end{array}$ \\
\hline $\begin{array}{l}\text { Incoming foreign } \\
\text { direct investment }\end{array}$ & $\begin{array}{c}0.0011^{* *} \\
(2.61)\end{array}$ & $\begin{array}{l}0.001^{*} \\
(1.65)\end{array}$ & $\begin{array}{l}0.0015^{* *} \\
(2.19)\end{array}$ & $\begin{array}{l}0.0015^{* *} \\
(2.07)\end{array}$ \\
\hline inflation & $\begin{array}{c}-0.00005 \\
(-0.13)\end{array}$ & $\begin{array}{c}-0.00005 \\
(-0.25)\end{array}$ & $\begin{array}{c}-0.00003 \\
(-0.06)\end{array}$ & $\begin{array}{c}-0.00003 \\
(-0.13)\end{array}$ \\
\hline $\mathrm{CO}_{2}$ emissions & $\begin{array}{c}0.1164 \\
(0.4)\end{array}$ & $\begin{array}{l}0.1164 \\
(0.83)\end{array}$ & $\begin{array}{l}0.0293 \\
(0.07)\end{array}$ & $\begin{array}{l}0.0293 \\
(0.24)\end{array}$ \\
\hline $\begin{array}{c}\text { Gross primary } \\
\text { school enrollment }\end{array}$ & $\begin{array}{c}0.0019^{*} \\
(1.77)\end{array}$ & $\begin{array}{l}0.0019^{* * *} \\
(3.20)\end{array}$ & $\begin{array}{c}0.0017^{*} \\
(1.92)\end{array}$ & $\begin{array}{c}0.0017^{* * *} \\
(3.51)\end{array}$ \\
\hline constant & $\begin{array}{l}0.2704^{* * *} \\
(3.06)\end{array}$ & $\begin{array}{l}0.2704^{* * *} \\
(3.66)\end{array}$ & $\begin{array}{c}0.3033^{* * *} \\
(6.74)\end{array}$ & $\begin{array}{c}0.3033^{* * *} \\
(5.00)\end{array}$ \\
\hline$\% \mathrm{R}^{2}$ & 53.26 & 53.26 & 50.73 & 50.73 \\
\hline Test de Pearsan & $\begin{array}{c}5.204 \\
(0.0000)\end{array}$ & & $\begin{array}{l}5.204 . \\
(0.0000)\end{array}$ & \\
\hline Number of Observations & 90 & 90 & 90 & 90 \\
\hline
\end{tabular}

Source: Author from Stata extracts. Values in parentheses are Student's t-test statistics. ${ }^{\star},{ }^{* *}$ and ${ }^{* * *}$ represent the $10 \%, 5 \%$ and $1 \%$ thresholds, respectively. 
$1 \%$ threshold. Thus, a $1 \%$ increase in external debt would lead to decreases of 0.0021 and $0.002 \%$ in the HDI in the three countries.

We note that the variables $\mathrm{CO}_{2}$ emissions, renewable energy consumption and inflation are not statistically significant. On the other hand, the variables human capital, GFCF and inward foreign direct investment are positive and significant at the $1 \%$ and $5 \%$ thresholds. Thus, a $1 \%$ increase in these variables leads to an improvement in the level of human development of $0.0017 \%, 0.001 \%$ and $0.0015 \%$ respectively

In view of these results, we can draw two major conclusions.

Renewable energy consumption: a marginal factor in improving human development.

Reading the results shows that renewable energy consumption has a positive sign but is not significant. This result corroborates the work of Tran et al. (2019), who found that energy consumption does not influence human development. Economically, this is explained by the orthodox approach, which holds that energy consumption has neutral effects on development, specifically human development (Jaruwan et al., 2006; Ongono, 2009).

This result can be explained in the EMCCA countries by the embryonic nature of renewable energy. Indeed, EMCCA countries have infrastructures that remain largely insufficient, which leads to a gap between supply and demand that is constantly widening. In the EMCCA, the gap between supply and demand is 190 to $270 \mathrm{MW}$, more than twice the total installed capacity of Congo. The rate of access to electricity is very low in the EMCCA, at 15\%. Thus, within the zone, Gabon (70\%) stands out clearly from Cameroon (22\%), CAR (2\%) and Chad (1\%). Thus, access to electricity remains an urban phenomenon, i.e., limited to large cities and, to a lesser extent, to small towns and villages. For example, in Cameroon and Congo, only $14 \%$ of the rural population on average has access to the grid, compared to $40 \%$ and $25 \%$ of the urban population, respectively.

The costs of electricity production, and therefore consumer prices, are among the most expensive in the world and weigh heavily on the public finances of governments (thermal power plants and diesel generators), on the balance sheet of companies (self-production, based in particular on expensive generators) and on the wallets of households (energy absorbs approximately $10 \%$ of income according to the World Bank). Thus, to compensate for the shortfall in clean energy, households resort to other forms of so-called nonrenewable energy.

Total energy consumption: a factor in improving human development in the EMCCA countries.

The table of estimation results shows that total energy consumption has a positive and significant effect at the $1 \%$ threshold on human development. Thus, a $1 \%$ increase in energy consumption leads to a $0.0002 \%$ increase in the level of human development. These results contradict the work of Ouedraogo (2013), who showed that energy consumption has a negative effect on human develop- 
ment in fifteen sub-Saharan countries. This supports the heterodox view that energy consumption is an indispensable factor for growth as well as human development.

In the EMCCA countries, an increase in energy consumption leads to an improvement in the standard of living. This fact can be explained by the strong potential of the subregion in terms of energy and the role that energy consumption plays in the lives of inhabitants. Indeed, Central Africa, and particularly the EMCCA, has significant potential in terms of fossil fuels, i.e., $15 \%$ of the continent's reserves, and biomass, with the second largest forest in the world. This potential stimulates the population to resort more to this type of energy than to renewable energies, whose costs in terms of accessibility or infrastructures are still reflective of the early stage of development in some countries.

Regarding the role of energy consumption in people's lives, energy services are indispensable for domestic and productive uses. At the household level, biomass and fossil fuels facilitate cooking and are used as a source of lighting, which has an influence on the level of education and health of these households. At the social level, fossil fuels are considered in these countries to be the main fuels. Thus, they provide services to more people and are also used as a resource alternative to clean and/or renewable energy. At the productive level, biomass represents nearly 60 million resources according to the White Paper report (ECCAS-EMCCA, 2014). We also note that fossil energies such as oil represent nearly 50 to $65 \%$ of the budgets of countries holding this resource. As a result, energy contributes to improving one of the components of the HDI, which is income. Therefore, we can conclude that energy consumption is an indispensable factor for human development.

\section{Conclusion and Policy Implications}

The purpose of this paper was to analyze the effects of energy consumption on human development. The analysis carried out via panel data econometrics and following the Driscoll \& Kraay (1998) technique has allowed us to draw two lessons in the context of these countries. The first is that renewable energy consumption is a marginal factor in improving human development, and the second is that total energy consumption is a factor in improving human development. In conclusion, the hypothesis of this paper can be rejected.

As a result, two policy implications have been identified. The first is to improve the level of energy in key development sectors (health, education, agriculture and industry) and in rural areas. To achieve this, energy must be made available to all. Governments must improve basic infrastructure and reduce the cost of energy by lowering the price of clean energy to avoid environmental degradation through the exploitation of more polluting sources.

The second implication is the development of the clean energy sector. Since investments in the energy sector are enormous, EMCCA governments must join forces to achieve levels of investment capable of meeting expectations. In fact, 
for several years now, the EMCCA and ECCAS governments have set themselves the objective of reaching an energy balance by 2025. Increased energy consumption, particularly of fossil fuels, has social and environmental consequences and costs at the local and regional levels. Thus, it would be interesting in future research to address the relationship between energy consumption and environmental degradation.

\section{Conflicts of Interest}

The authors declare no conflicts of interest regarding the publication of this paper.

\section{References}

Apergis, N., \& Payne, J. E. (2009). Energy Consumption and Economic Growth in Central America: Evidence from a Panel Cointegration and Error Correction Model. Energy Economics, 31, 211-216. https://doi.org/10.1016/j.eneco.2008.09.002

Bai, J., \& Ng, S. (2004). A Panic Attack on Unit Roots and Cointegration. Econometrica, 72, 1127-1177. https://doi.org/10.1111/j.1468-0262.2004.00528.x

Becker, G. S., Murphy, K., \& Tamura, R. (1990). Human Capital Fertility and Economic Growth. Journal of Political Economy, 93, 512-537. https://doi.org/10.1086/261723

Belke, A., Dreger, C., \& de Haan, F. (2010). Energy Consumption and Economic Growth New Insights into the Cointegration Relationship (pp. 1-22). Ruhr Economic Papers No. 190. https://doi.org/10.2139/ssrn.1635765

Breitung, J. (2003). Nonparametric Tests for Unit Roots and Cointégration. Journal of Econometrics, 117, 401-404. https://doi.org/10.1016/S0304-4076(03)00217-3

Chiroleu-Assouline, M. (2001). Le double dividende: Les approches theoriques. Revue Française d'Economie, 16, 119-147. https://doi.org/10.3406/rfeco.2001.1510

Choi, I. (2001). Unit Root Tests for Panel Data. Journal of International Money and Finance, 20, 249-272. https://doi.org/10.1016/S0261-5606(00)00048-6

Driscoll, J., \& Kraay, A. C. (1998). Consistent Covariance Matrix Estimation with Spatially Dependent Data. Review of Economics and Statistics, 80, 549-560. https://doi.org/10.1162/003465398557825

George, E. H., \& Nickoloas, G. T. (2011). The Effect of Energy Consumption on Economic Growth on Countries Economic Efficiency: A Conditional Nonparametric Approach. MPRA Paper No. 28692.

Georgescu-Roegen, N. (1979). Energy and Matter in Mankind's Technological Circuit. Journal of Business Administration, 10, 107-127. https://doi.org/10.1111/j.1468-2257.1979.tb00819.x

Hadri, K. (2000). Testing for Stationarity in Heterogeneous Panel Data. The Econometrics Journal, 3, 148-161. https://doi.org/10.1111/1368-423X.00043

Hansen, J.-P., \& Percebois, J. (2010). Energie (p. 779). Paris: De Boeck.

Hoechle, D. (2007). Robust Standard Errors for Panel Regressions with Cross-Sectional Dependence. The Stata Journal, 7, 281-312. https://doi.org/10.1177/1536867X0700700301

Hosier, R., \& Dowd, J. (1987). Household Fuel Choice in Zimbabwe: An Empirical Test of the Energy Ladder Hypothesis. Resources and Energy, 9, 347-361.

https://doi.org/10.1016/0165-0572(87)90003-X 
Im, K. S., Pesaran, M. H., \& Shin, Y. (2003). Testing for Unit Roots in Heterogeneous Panels. Journal of Econometrics, 115, 53-74. https://doi.org/10.1016/S0304-4076(03)00092-7

Jaruwan, C., Hunt, L. C., \& Pierse, R. (2006). Causality between Energy Consumption and GDP: Evidence from $30 \mathrm{OECD}$ and 78 Non-OECD Countries. University of Surrey Department of Economics.

Jumbe, C. (2004). Cointegration and Causality between Electricity Consumption and GDP: Empirical Evidence from Malawi. Energy Economics, 26, 61-68. https://doi.org/10.1016/S0140-9883(03)00058-6

Kanagawa, M., \& Nakata, T. (2008). Assessment of Access to Electricity and the Socioeconomic Impacts in Rural Areas of Developing Countries. Energy Policy, 36, 2016-2029. https://doi.org/10.1016/j.enpol.2008.01.041

Kané, C. S. (2009). Demande d'énergie et croissance économique dans l'UEMOA. Revue Africaine De L'intégration, 3, 191-221.

Karekezi, S., McDade, S., Boardman, B., \& Kimani, J. (2012). Global Energy Assessment: Toward a Sustainable Future (pp. 151-190). Cambridge: Cambridge University Press.

Kazar, G., \& Kazar, A. (2014). The Renewable Energy Production-Economic Development Nexus. International Journal of Energy Economics and Policy, 4, 312-319.

Kraft, J., \& Kraft, A. (1978). On the Relationship between Energy and GNP. Journal of Energy and Development, 3, 401-403.

Leach, G. (1992). The Energy Transition. Energy Policy, 20, 116-123. https://doi.org/10.1016/0301-4215(92)90105-B

Lékana, H. C., \& Ndinga, M. M. A. (2020). Analyse des déterminants de l'intensité énergétique dans les pays membres de la CEMAC. Revuecedres-Etudes- $\mathrm{N}^{\circ} 69$ Séries économie-1er Semestre 2020.

Levin, A. C., Lin, F., \& Chu, C. S. J. (2002). Unit Root Tests in Panel Data: Asymptotic and Finite-Sample Properties. Journal of Econometrics, 108, 1-24.

https://doi.org/10.1016/S0304-4076(01)00098-7

Maddala, G. S., \& Wu, S. (1999). A Comparative Study of Unit Root Tests with Panel Data and a New Simple Test. Oxford Bulletin of Economics and Statistics, 61, 631-652. https://doi.org/10.1111/1468-0084.0610s1631

Martinez, D. M., \& Ebenhack, B. W. (2008). Understanding the Role of Energy Consumption in Human Development through the Use of Saturation Phenomena. Energy Policy, 36, 1430-1435. https://doi.org/10.1016/j.enpol.2007.12.016

Menegaki, A. N. (2011). Growth and Renewable Energy in Europe: A Random Effect Model with Evidence for Neutrality Hypothesis. Energy Economics, 33, 257-263. https://doi.org/10.1016/j.eneco.2010.10.004

Moon, H., \& Perron, B. (2004). Testing for a Unit Root in Panels with Dynamic Factors. Journal of Econometrics, 122, 81-126. https://doi.org/10.1016/j.jeconom.2003.10.020

Ndinga, M. M. A., Akouele, A. F., \& Lekana, H. C. (2017). Effets des savoirs et des connaissances sur la diversification des économies de la Communauté Économique et Monétaire de l'Afrique Centrale (CEMAC). Revue Cedres-Etudes- $\mathrm{N}^{\circ} 64$ Séries économie2ie Semestre 2017.

Newey, W. K., \& West, K. D. (1987). A Simple, Positive Semi-Definite, Heteroskedasticity and Autocorrelation Consistent Covariance Matrix. Econometrica, 55, 703-708. https://doi.org/10.2307/1913610

Nguyen, K. H., \& Kakinaka, M. (2019). Renewable Energy Consumption, Carbon Emis- 
sions, and Development Stages: Some Evidence from Panel Cointegration Analysis. Renewable Energy, 132, 1049-1057. https://doi.org/10.1016/j.renene.2018.08.069

Niu, S., Jia, Y., Wang, W., He, R., Hu, L., \& Liu, Y. (2013). Electricity Consumption and Human Development Level: A Comparative Analysis Based on Panel Data for 50 Countries. International Journal of Electrical Power \& Energy Systems, 53, 338-347. https://doi.org/10.1016/j.ijepes.2013.05.024

Ongono, P. (2009). Energy Consumption and Economic Performance in Cameroon. Yaounde: University of Yaounde II, Faculty of Economics and Management/MPRA Paper No. 23525. http://mpra.ub.uni-muenchen.de/23525

Ouedraogo, N. S. (2013). Energy Consumption and Human Development: Evidence from a Panel Cointegration and Error Correction Model. Energy, 63, 28-41. https://doi.org/10.1016/j.energy.2013.09.067

Ozokcu, S., \& Özdemir, Ö. (2017). Regression with Driscoll-Kraay Standard Errors. Renewable \& Sustainable Energy Reviews, 72, 639-647. https://doi.org/10.1016/j.rser.2017.01.059

Pasternak, A. D. (2000). Global Energy Futures and Human Development: A Frameworkfor Analysis. Oak Ridge, TE: US Department of Energy.

Persyn, D., \& Westerlund, J. (2008). Error Correction Based Cointegration Tests for Panel Data. Stata Journal, 8, 232-241. http://hdl.handle.net/10536/DRO/DU:30078217 https://doi.org/10.1177/1536867X0800800205

Pesaran, M. H. (2004). General Diagnostic Tests for Cross Section Dependence in Panels. IZA Discussion Paper 1240 and CESifo Working Paper 1229.

Pirlogea, C. (2012). The Human Development Relies on Energy. Panel Data Evidence. Procedia Economics and Finance, 3, 496-501. https://doi.org/10.1016/S2212-5671(12)00186-4

Sarkodie, S. A., \& Strezov, V. (2019). Effect of Foreign Direct Investments, Economic Development and Energy Consumption on Greenhouse Gas Emissions in Developing Countries. Science of the Total Environment, 646, 862-871. https://doi.org/10.1016/j.scitotenv.2018.07.365

Sen, A. (1992). Food and Feedrom. In K. Basu, \& P. Nayak (Eds.), Development Policy and Economic Theory (323 p). Oxford: Oxford University Press.

Sen, A. (1999). Development as Freedom. Oxford: Oxford University Press.

Sinha, A., \& Sen, S. (2016). Atmospheric Consequences of Trade and Human Development: A Case of BRIC Countries. Atmospheric Pollution Research, 7, 980-989. https://doi.org/10.1016/j.apr.2016.06.003

Solow, R. M. (1956). A Contribution to the Theory of Economic Growth. Quarterly Journal of Economics, 70, 65-94. https://doi.org/10.2307/1884513

Stern, D. I. (2012). Modeling International Trends in Energy Efficiency. Energy Economics, 34, 2200-2208. https://doi.org/10.1016/j.eneco.2012.03.009

UNCTAD (2017). Rapport 2017 sur les pays les moins avancés: L'accès à l'énergie comme vecteur de transformation. Numéro F.17.II.D.6. CNUCED. https://unctad.org/system/files/official-document/ldcr2017_fr.pdf

UNDP (United Nations Development Programme) (2015). Universal Access T Modern Energy for the Pool.

http://www.undp.org/content/dam/aplaws/publication/en/publications/environment-e $\underline{\text { ner- }}$ 
gy/www-ee-library/climate-change/undp-and-energy-access-for-the-poor/2593.Energy Access_Booklet_Revision02.pdf?download

UNDP (United Nations Development Programme) (2019). Au-delà des revenus, des moyennes et du temps présent: Les inégalités de développement humain au XXIe siècle. New York: One United Nations Plaza. http://www.undp.org

Van Tran, N., Van Tran, Q., Do, L. T. T., Dinh, L. H., \& Do, H. T. T. (2019). Trade Off between Environment, Energy Consumption and Human Development: Do Levels of Economic Development Matter? Energy, 173, 483-493.

https://doi.org/10.1016/j.energy.2019.02.042

Wang, Z., Bui, Q., Zhang, B., Nawarathna, C. L. K., \& Mombeui, C. (2020). The Nexus between Renewable Energy Consumption and Human Development in BRICS Countries: The Moderating Role of Public Debt. Renewable Energy, 165, 381-390.

https://doi.org/10.1016/j.renene.2020.10.144

Wang, Z., Danish, Zhang, B., \& Wang, B. (2018). Renewable Energy Consumption, Economic Growth and Human Development Index in Pakistan: Evidence form Simultaneous Equation Model. Journal of Cleaner Production, 184, 1081-1090.

https://doi.org/10.1016/j.jclepro.2018.02.260

Westerlund, J. (2007). Testing for Error Correction in Panel Data. Oxford Bulletin of Economics and Statistics, 69, 709-748.

https://doi.org/10.1111/j.1468-0084.2007.00477.x 